\title{
Comparison analysis of numerically calculated slip surfaces with measured S-wave velocity field for Just-Tęgoborze landslide in Carpathian flysch
}

\author{
Krzysztof Krawiec*, Paulina Harba \\ Mineral and Energy Economy Research Institute of the Polish Academy of Sciences, Cracow, Poland
}

\begin{abstract}
The article presents the comparison analysis between deformation field from numerical model and shear wave (S-wave) velocity field obtained from seismic interferometry (SI). Tests were conducted on active Just-Tęgoborze landslide. Geologically, the study area lies in Magura Nappe in the Outer Carpathians. The landslide's flysch bedrock is covered by Quaternary colluvium built of clays and weathered clayey-rock deposits. During geotechnical investigation, properties of landslide body were established and failure surfaces were distinguished. In order to obtain Swave velocity models, one-hour of ambient seismic noise was recorded by 12 broadband seismometers. As a result of data processing with SI method, Rayleigh surface wave propagation was reconstructed. The analysis of dispersion curves allowed to estimate a two dimensional S-wave velocity field. The deformation field were calculated assuming an elastic-plastic Coulomb-Mohr strength criterion. Images of shear strain increment, and values of factor of safety of the slope were obtained as a result of calculation. The comparison of the results indicates the similar characteristic features in the S-wave velocity field and the field of deformation calculated numerically.
\end{abstract}

Keywords: numerical modelling, S-wave velocity, seismic interferometry, landslide, slip surface

\section{Introduction}

Recognition and characterization of the slopes prone to mass movements are the main tasks in landslide hazard evaluation [1,2]. Geophysical methods provide relatively fast recognition of the landlides' subsurface and they are a great complement to standard geological and geotechnical investigations [3-7]. In the last decades, seismic interferometry as a passive seismic method, has been developed and successfully applied to landslide subsurface characterization and monitoring mass movements, with the analysis of shear wave (S-wave) velocity field $[6,8-13]$.

\footnotetext{
*Corresponding author: k.krawiec@meeri.eu
} 
According to [14] clear understanding of the considered phenomena (e. g. landslide) during the seismic data interpretation is crucial to allow reliable data analysis. The slope stability analysis is often performed with use of numerical modelling and could be very helpful for better comprehension of landslide phenomena. Shear strength reduction method (SSR) is widely applied for numerical two-dimensional (2D) and three-dimensional (3D) stability analyses [15]. The advantages and disadvantages of SSR method over the limit equilibrium method were discussed in $[16,17]$.

In the article, we present a comparison study of S-wave velocity field obtained from seismic interferometry and the results of slope stability analysis obtained from numerical calculations for Just-Tęgoborze landslide. We performed a field measurements of ambient seismic noise to obtain the S-wave velocity map of landslide subsurface. We also conducted the stability analysis with use of numerical modelling program to get the information about possible course of slip surfaces. The comparison of S-wave velocity field and the results of numerical analysis helps us in better interpretation of seismic boundaries.

\section{Geological conditions}

Just-Tęgoborze landslide is located in southern Poland, on the area of Świdnik and Tęgoborze in Nowy Sącz county (fig. 1). It extends from St. Just Pass between Jodłowiec Wielki Mountain and St. Just Mountain with height of $435 \mathrm{~m}$ a.s.1., down to the Rożnów Lake with height of $285 \mathrm{~m}$ a.s.1.



Fig. 1. Location of the Just-Tęgoborze landslide [12].

Just-Tęgoborze landslide lies in Magura Nappe in the Outer (Flysch) Carpathians [12, 18]. On the research area, Magura Nappe is represented by southern and northern Rača subunits. Southern Rača subunit consists of hieroglyphic beds of age of middle and lower Eocene and Magura beds of age of upper Eocene - Oligocene. Hieroglyphic beds are mainly built of thin-bedded sandstones and shales. In the upper part, they are interbedded with medium and thick-bedded sandstones, whereas, in the lower part, shales constitute a majority. Magura beds consist of muscovitic sandstones of 0.7-2 m thickness. Northern Rača subunit exposes on a small part of landslide area, between Łososina valley and the northern border of Magura Nappe [19]. It is represented by Sub-Magura beds of age of middle Eocene Oligocene. They are built of sandstones and shales. 
Just-Tęgoborze landslide is located on the area of complicated tectonics between Magura, Sub-Magura and hieroglyphic beds [20]. It is due to the fact that Magura sandstones are more resistant than shale and shale-sandstone complexes of Sub-Magura and hieroglyphic beds. Another reason for landslide movements is constituted by the occurrence of weak variegated shales prone to swelling and highly tectonic disturbances. Landslide movements usually occur during intensive infiltration of water from spring thaws or long-lasting rainfalls [12].

Landslide colluvium is made of clays, weathered clays and weathered flysch rocks i.e. sandstones and shales. It has a maximum thickness of approx. $30 \mathrm{~m}$ (fig. 3). Clayey colluvium has been differentiated into plastic, semi-solid and solid.

According to a borehole data a few slip surfaces were distinguished. One on the contact between rock weathering colluvium and less weathered flysch bedrock, and at least two within landslide colluvium. Mainly the slip surfaces located within colluvial deposits have a strong influence on slope stability and are the direct threat to the state road no. 75 and the infrastructure in the vicinity.

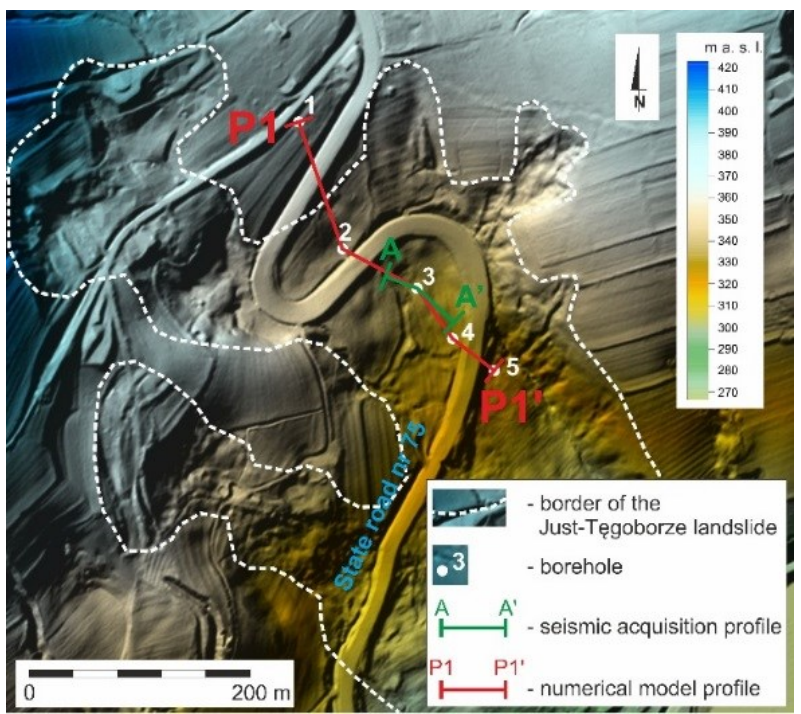

Fig. 2. Range of the Just-Tęgoborze landslide (based on the data from Central State Geodetic and Cartographic Resource).

Based on the data from the boreholes, which locations are shown on the figure 2, the crosssection along the $\mathrm{P} 1-\mathrm{P} 1$ ' profile was prepared (fig. 3).



Fig. 3. Cross-section along the P1 - P1' profile of the Just-Tęgoborze landslide. A-A' indicates seismic profile. 


\section{Methodology}

\subsection{Numerical modelling}

In order to determine the factor of safety of the slope (FoS), a numerical simulation was carried out on the basis of the cross-section determined along P1-P1' profile (fig. 3). Model geometry was constructed on the basis of data obtained from geotechnical boreholes. The length of the model was $277 \mathrm{~m}$. The left frame of the model was $91.5 \mathrm{~m}$ high, while the right - $42.5 \mathrm{~m}$. Based on geological and engineering data, four layers were defined in the model. Strength parameters adopted for calculations are presented in Table 1. The impact of water was taken into account by reducing the values of strength parameters taken from [21] on the basis of EUROKOD 7 guidelines [22].

Table 1. Physical-mechanical properties of the geological layers on the base of [21].

\begin{tabular}{|l|l|l|l|}
\hline Layer name & $\begin{array}{l}\text { Volumetric } \\
\text { density }\left[\mathrm{kg} / \mathrm{m}^{3}\right]\end{array}$ & Cohesion $[\mathrm{kPa}]$ & $\begin{array}{l}\text { Internal friction } \\
\text { angle }\left[{ }^{\circ}\right]\end{array}$ \\
\hline Clayey colluvium (plastic) & 2100 & 13.5 & 9 \\
\hline Clayey colluvium (semi-solid) & 2150 & 17.25 & 11 \\
\hline Rock weathering colluvium & 2420 & 17.25 & 11 \\
\hline Shales/Sandstones & 2500 & 75.0 & 32 \\
\hline
\end{tabular}

Values of Young modulus and Poisson ratio was the same for all layers and were respectively $82 \mathrm{MPa}$ and 0.36

In the calculation model, a discretization mesh with a mesh size of $1.0 \times 1.0 \mathrm{~m}$ was introduced. As a result, 34200 computational elements were obtained. Boundary conditions have been introduced in such a way as to block the possibility of horizontal displacements on the right and left frames, and on the bottom frame both the vertical and horizontal displacements. The surface of the model was a free surface in which displacements were possible in each direction. The simulation was performed in a plane strain state. A linear elastic perfectly plastic model was adopted, with use of the Coulomb-Mohr strength criterion.

The calculations were made in a FLAC v. 8.0 program based on the finite difference method, in which the slope factor of safety is obtained using strength reduction method [16, 17, 23-25]. In addition the FLAC code give a possibility to compute multiple factors of safety along a complex slope profile $[16,24,26]$.

\subsection{Seismic interferometry}

\section{Acquisition}

Seismic interferometry acquisition was conducted along the A-A' profile which went through the borehole 3 shown on the figure 3 . Local seismic noise generated by intense vehicle traffic was registered by 12 Güralp CMG-6TD three-component broadband seismometers which were installed along the profile A-A'. Seismic noise came from three directions which allowed to obtain sufficient seismic noise recordings during 60 minutes. Intervals between seismometers were $10 \mathrm{~m}, 15 \mathrm{~m}$ and $20 \mathrm{~m}$.

\section{Processing and interpretation}

Seismic noise registrations were band-pass filtered in the 7 to $20 \mathrm{~Hz}$ frequency band. Next, 1-bit amplitude normalization was applied. As a result of cross-correlation, series of empirical Green's functions were calculated between all seismometer pairs. Then, the application of frequency-wavenumber (f-k) transform allowed to separate surface wave energy from body waves. It led to obtain dispersion images of Rayleigh surface waves. 
Analysis of dispersion was based on picking fundamental modes of Rayleigh wave dispersion curves. Next, inversion was applied using genetic algorithm which parameters were as follows: number of population: 128; exponential stretch function; crossover probability: 0,9 ; mutation probability 0,02 . As a result, $1 \mathrm{D} \mathrm{S}$-wave velocity models were obtained and finally 2D S-wave velocity section was visualized. More detailed description of SI processing and interpretation on Just-Tęgoborze landslide is presented in [12].

\section{Results and analysis}

\subsection{Numerical modelling}

As a result of numerical modelling three main slip surfaces along the P1-P1' profile were indicated (fig. 4). Two of them, which factor of safety value is 1.5 or less, are located within the layer closest to the surface (plastic clayey colluvium). The FoS values are not enough to provide slope stability especially in case of heavy rainfalls or intense traffic. The third slip surface is located deeper and goes through the border between bedrock and rock weathering colluvium. The slip surfaces are located in direct vicinity of the state road no 75 . Its course partly overlaps the course of A-A' seismic profile.

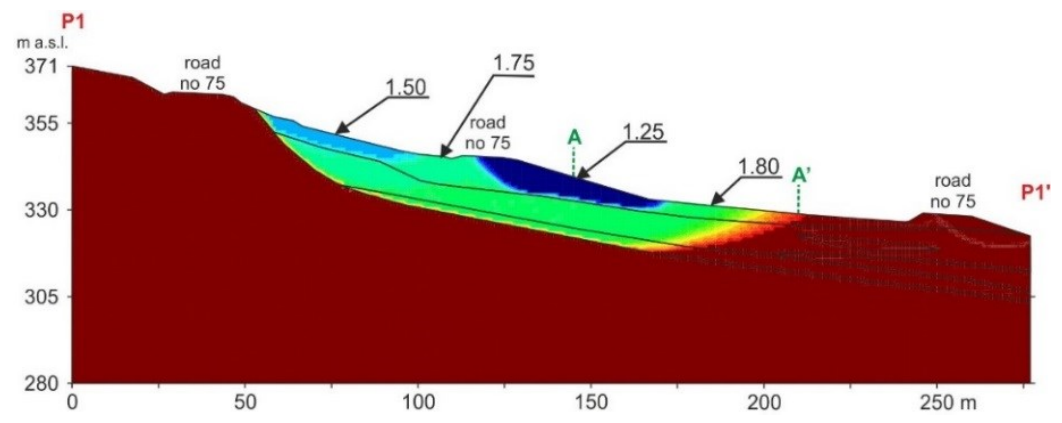

Fig. 4. Factor of safety contours on Just-Tęgoborze landslide along P1-P1' profile obtained from numerical calculations.

Figure 5 shows the development of shear strain increment during stability calculations. The greatest values of shear strains accumulates within the lower part of the weakest slip surface between 150 and $165 \mathrm{~m}$ of P1-P1'. Strong accumulations of the shear strains could be also observed within the layer of rock weathering colluvium between 140 and $160 \mathrm{~m}$ of P1-P1' profile.

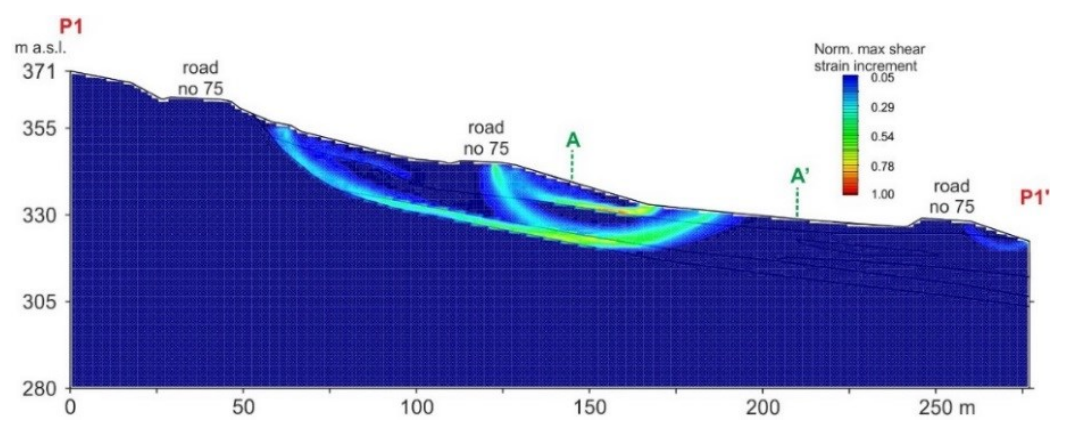

Fig. 5. Normalized shear strain increment on Just-Tęgoborze landslide along P1-P1' during slope stability numerical calculations. 
The outcrop of the deeper slip surface between the 180 and $190 \mathrm{~m}$ of P1-P1' profile could be connected with the occurrence of transverse ridges of the slope which are visible on the terrain surface of the study area (fig. 6).



Fig. 6. Possible occurrence of transverse ridge on the terrain surface of the study area. The sketch on the upper left corner is based on [27].

\subsection{Seismic interferometry}

As a result of processing and interpretation, seismic cross section of shear wave velocity field was obtained (fig. 7).

On the seismic section, three main zones of seismic velocity are clearly visible. The zone with the smallest S- wave velocities from $180-270 \mathrm{~m} / \mathrm{s}$ is located the closest to the terrain surface. Its thickness ranges from 6 to 10 meters. Velocities from the range 270-340 m/s indicate the next velocity zone with an average thickness of 5-6 meters. The deepest-located layer is characterized by the S-wave velocity values higher than $340 \mathrm{~m} / \mathrm{s}$. The roof of this layer occurs at the depth of 10 to $15 \mathrm{~m}$.

Regarding the geological-engineering cross-section, we can correlate the near surface Swave velocity layer with the clayey colluvium - it is particularly prone to changes caused by water infiltration. Second seismic layer we can correlate with the weathered clays with rock fragments of shales and sandstones and weathered shales and variegated shales. Seismic boundary with the velocity of $340 \mathrm{~m} / \mathrm{s}$ indicates less weathered variegated shales interbedded by sandstones which are considered as the flysch bedrock.

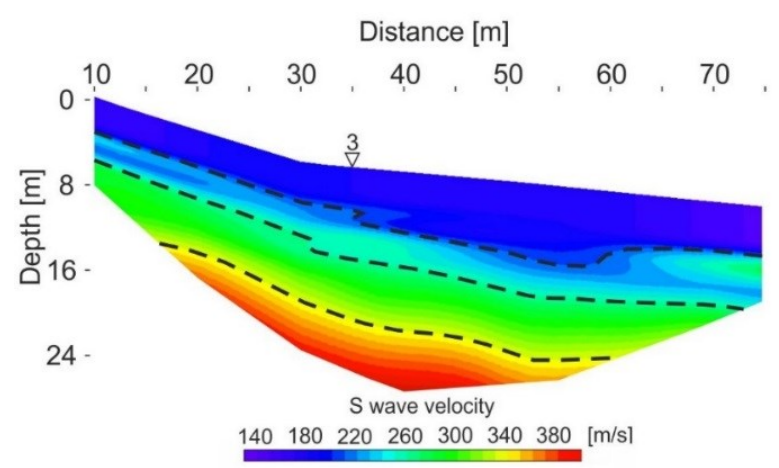

Fig. 7. S-wave velocity section from seismic interferometry with seismic noise gained on JustTęgoborze landslide along A-A' seismic profile. Black thick dashed lines indicates interpreted seismic borders ( 3 denotes borehole point). 


\subsection{Comparison analysis}

To better understand the interpretation of seismic layers we try to correlate it with the results of numerical calculations. By superimposing a map of S-wave velocity and map of shear strain increment obtained from numerical modeling we could make comparative analysis (fig. 8). In general, the slip surfaces only coincide to some extent with interpreted seismic boundaries. It is worth emphasizing the fairly good compatibility of the location of the upper slip surface, indicated as I, with the shallowest seismic boundary of clay colluvium. In the conditions of strong rainfalls, landslide processes could be reactivated in this colluvium.

The location of the II slip surface along flysch bedrock corresponds to the location of the third seismic boundary between weathered shales and flysch bedrock. Both borders coincide over a small section, but it is clearly seen that they form a logical continuity. However, there are no distinct changes in the S-wave velocity field associated with the curvature of slip surfaces I and II towards the terrain surface.



Fig. 8. Superimposing map of S-wave velocity on the map of shear strain increment. The color scales of both of the maps are the same like on the figures 5 and 6 respectively. Grey contours indicate the continuity of shear strain increment of two slip surfaces described as I and II.

\section{Conclusions}

This article presents a comparison study of S-wave velocity field obtained from seismic interferometry and the results of numerical stability analysis for Just-Tęgoborze landslide. Based on the outcomes of the conducted research, the following conclusions were drawn:

1. As a result of numerical stability analysis three main slip surfaces along the P1-P1' profile were indicated. Two of them are located within the shallowest clayey colluvium. The third slip surface goes along bedrock border.

2. Three main layers of S-wave velocity were indicated on the basis of seismic interferometry:

I. velocities from $180-270 \mathrm{~m} / \mathrm{s}$ (thickness $6-10 \mathrm{~m}$ ) could be connected with the clayey colluvium, prone to changes caused by water infiltration,

II. velocities from $270-340 \mathrm{~m} / \mathrm{s}$ (thickness 5-6 m) could be connected with the weathered clays with rock fragments of shales and sandstones and weathered shales and variegated shales,

III. velocities higher than $340 \mathrm{~m} / \mathrm{s}$ (starts at the depth of 10 to $15 \mathrm{~m}$ ) could be connected with less weathered variegated shales interbedded by sandstones which are considered as the flysch bedrock. 
3. Superimposing of S-wave velocity cross-section and cross-section of shear strain increment obtained from numerical modelling let us to draw following remarks:

a. the slip surfaces only coincide to some extent with interpreted seismic boundaries,

b. fairly good compatibility of the location of the upper slip surface with the shallowest seismic boundary of clay colluvium was obtained,

c. the location of the deepest slip surface along flysch bedrock corresponds to the location of the third seismic boundary between weathered shales and flysch bedrock.

d. no distinct changes were observed in the measured S-wave velocity field associated with the curvature of slip surfaces towards the terrain surface.

\section{References}

1. F. Guzzetti, A. Carrara, M. Cardinali, P. Reichenbach, Landslide hazard evaluation: a review of current techniques and their application in a multi-scale study, Central Italy, Geomorphology 31, 181-216 (1999)

2. K. Sassa, G. Wang, H. Fukuoka, F. Wang, T. Ochiai, M. Sugiyama, T. Sekiguchi, Landslides 1, 221-235 (2004) doi: 10.1007/s10346-004-0028-y

3. A.I. Kanli, Integrated approach for surface-wave analysis from near-surface to bedrock In: Advances in near-surface seismology and ground-penetrating radar, J.H. Bradford, H. Klaus, R.D. Miller (eds) Society of Exploration Geophysicists, Tulsa, 461-476 (2010) doi: 10.1190/1.9781560802259.ch29

4. Z. Pilecki, E3S Web Conf 24, 01001 (2017) doi: 10.1051/e3sconf/20172401001

5. J.S. Whiteley, J.E. Chambers, S. Uhlemann, P.B. Wilkinson, J.M. Kendall, Rev Geophys 57, 1-40, (2019) doi: 10.1029/2018RG000603

6. P. Harba, Z. Pilecki, K. Krawiec, Acta Geophys, 1-9 (2019) doi: 10.1007/s11600-01900344-9

7. D. Huntley, P. Bobrowsky, M. Hendry, R. Macciotta, M. Best, J Environ Eng Geophys 24(1), 87-110 (2019) doi: 10.2113/JEEG24.1.87

8. F. Renalier, G. Bièvre, D. Jongmans, M. Campillo, P.-Y. Bard, Clayey landslide investigations using active and passive VS measurements, In: Advances in near-surface seismology and groundpenetrating radar, Society of Exploration Geophysicists, 397-413 (2010a) doi: 10.1190/1.97815 60802 259.ch24

9. F. Renalier, D. Jongmans, M. Campillo, P.-Y. Bard, J Geophys Res 115(F3), 1-14 (2010b) doi: 10.1029/2009JF0015 38

10. G. Mainsant, E. Larose, C. Brönnimann, D. Jongmans, C. Michoud, M. Jaboyedoff, J Geophys Res Earth Surf 11,7 1-12 (2012) doi: 10.1029/2011J F002159

11. E. Larose, S. Carriere, C. Voisin, P. Bottelin, L. Baillet, P. Guéguen, F. Walter, D. Jongmans, B. Guillier, S. Garambois, F. Gimbert F, Ch. Massey, J Appl Geophys 116, 62-74 (2015) doi : 10.1016/j.jappg eo.2015.02.001

12. P. Harba, Z. Pilecki, Landslides 14, 1225-1233 (2017) doi: 10.1007/s10346-016-0779-2

13. Y. Hussain, H. Hertinez-Carvajal, M. Cárdenas-Soto, R. Uagoda, J.E. Soares, S. Martino Seasonal monitoring of hydrological stresses developed by varying degree of rainfall induced pore-pressures using noise data In: 15th International congress of the Brazilian 
geophysical society at Rio de Janeiro. SBGf_-Sociedade Brasileira de Geofísica 2017, 1727-1729 (2017) doi : 10.1190/sbgf2017-340

14. G. Dal Moro, Surface wave analysis for near surface applications, Elsevier, Amsterdam, The Netherlands, 252 (2014), ISBN 9780128007709

15. M. Cała, M. Kowalski, A. Stopkowicz, Arch Min Sci 59(3) 609-620 (2014) doi: 10.2478/amsc-2014-0043

16. M. Cała, J. Flisiak, Slope stability analysis with FLAC and limit equilibrium methods. FLAC and Numerical Modeling in Geomechanics - 2001 (ed. Bilaux et al.), A.A. Balkema Publishers, 111-114 (2001)

17. M. Cała, Arch Min Sci 52 (1), 75-89 (2007)

18. J. Stanisz, Z. Pilecki, E3S Web of Conferences 66, 02001 (2018), doi: $10.1051 / \mathrm{e} 3$ sconf/20186602001

19. M. Cieszkowski, A. Waskowska, Zamki znad jezior Rożnowskiego i Czchowskiego jako geoturystyczne lapidaria i rola piaskowców istebniańskich $w$ ich powstaniu (Castles from the Rozinów and Czchow lakes area as geotouristic lapidarium and role of the Istebna Sandstones in their construction), Geotourism 2 (21), 3-18 (2010) (in Polish)

20. W. Zuchiewicz, Utwory czwartorzędowe Pogórza Rożnowskiego $w$ Karpatach Zachodnich (Quaternary deposits of the Rożnów Foothills, Polish West Carpathians) Przegląd Geologiczny 38 (7-8), 310 (1990) (in Polish with English summary).

21. G Czudec, Dokumentacja geologiczno-inzynierska dla opracowania systemu zabezpieczenia strefy osuwiskowej $\mathrm{nr}$ MPL0051, w ciagu drogi krajowej $\mathrm{nr} 75, \mathrm{~km}$ od 51+900 do 52+700 w miejscowosci Tegoborze-Just, gm. Lososina Dolna, pow. nowosadecki, woj. malopolskie (Geological-engineering documentation for developing landslide stabilization no. MPL0051, on the state road no. 75, 51+900 do 52+700 km in Tegoborze-Just, Lososina Dolna commune, Nowy Sacz county, Malopolskie voivodeship), Geotech Sp. z o.o. Archive no. 1266 (2012) (in Polish) - unpublished data

22. EN 1997-1 Eurokod 7. Geotechnical design. Part 1: General rules

23. G. M. Peschl, Reliability analysis in geotechnics with the random set finite element method. PhD thesis. Graz: Graz University of Technology (2004)

24. FLAC v. 8.0., 2016. Factor of Safety. Itasca Consulting Group. Minneapolis, USA

25. Z. Pilecki, J. Stanisz, K. Krawiec, H. Wozniak, E. Pilecka, Numeryczna analiza stateczności skarp i zboczy z wykorzystaniem metody zbiorów losowych (Numerical stability analysis of slope with use of Random Set Theory) Zeszyty Naukowe IGSMiE PAN 86, 5-17 (2014) (in Polish)

26. Y. M. Cheng, T. Lansivaara, W. B. Wei, Comput Geotech 34, 137-150 (2007)

27. L. M. Highland, P. Bobrowsky, The landslide handbook: a guide to understanding landslides; U.S. Geological Survey, Circular 1325, 129 (2008) 